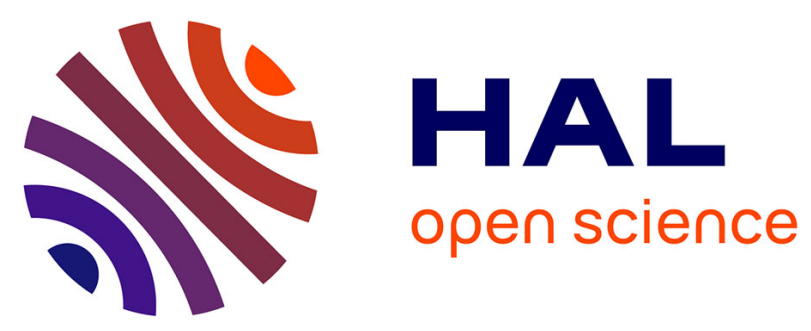

\title{
In vitro protective effects of Withania somnifera (L.) Dunal root extract against hydrogen peroxide and $\beta$-amyloid(1-42) induced cytotoxicity in differentiated PC12 cells
}

Suresh Kumar, Christopher John Seal, Melanie-Jayne Howes, Geoffrey C Kite, Edward Jonathan Okello

\section{To cite this version:}

Suresh Kumar, Christopher John Seal, Melanie-Jayne Howes, Geoffrey C Kite, Edward Jonathan Okello. In vitro protective effects of Withania somnifera (L.) Dunal root extract against hydrogen peroxide and $\beta$-amyloid(1-42) induced cytotoxicity in differentiated PC12 cells. Phytotherapy Research, 2010, 24 (10), pp.1567. 10.1002/ptr.3261 . hal-00599838

\section{HAL Id: hal-00599838 https://hal.science/hal-00599838}

Submitted on 11 Jun 2011

HAL is a multi-disciplinary open access archive for the deposit and dissemination of scientific research documents, whether they are published or not. The documents may come from teaching and research institutions in France or abroad, or from public or private research centers.
L'archive ouverte pluridisciplinaire HAL, est destinée au dépôt et à la diffusion de documents scientifiques de niveau recherche, publiés ou non, émanant des établissements d'enseignement et de recherche français ou étrangers, des laboratoires publics ou privés. 


\section{In vitro protective effects of Withania somnifera (L.) Dunal root extract against hydrogen peroxide and $\beta$-amyloid(1- 42 ) induced cytotoxicity in differentiated PC12 cells}

\begin{tabular}{|r|l|}
\hline Journal: & Phytotherapy Research \\
\hline Manuscript ID: & PTR-10-0172.R2 \\
\hline Wiley - Manuscript type: & Full Paper \\
\hline Author: & 07-Jun-2010 \\
\hline Complete List of Authors: & $\begin{array}{l}\text { Kumar, Suresh; Newcastle University, Medicinal Plant Research } \\
\text { Group, School of Agriculture, Food \& Rural Development } \\
\text { Seal, Christopher; Newcastle University, Medicinal Plant Research } \\
\text { Group, School of Agriculture, Food \& Rural Development } \\
\text { Howes, Melanie-Jayne; Royal Botanic Gardens, Kew, Jodrell } \\
\text { Laboratory } \\
\text { Kite, Geoffrey; Royal Botanic Gardens, Kew, Jodrell Laboratory, } \\
\text { Richmond, } \\
\text { Okello, Edward; Newcastle University, Medicinal Plant Research } \\
\text { Group, School of Agriculture, Food \& Rural Development; Newcastle } \\
\text { University, Institute of Neuroscience }\end{array}$ \\
\hline Keyword: & $\begin{array}{l}\text { Withania somnifera, neuroprotection, hydrogen peroxide, amyloid, } \\
\text { cytotoxicity, Alzheimer's disease }\end{array}$ \\
\hline \hline
\end{tabular}

\section{今scholarONE" \\ Manuscript Central}




\title{
In vitro protective effects of Withania somnifera (L.) Dunal root extract

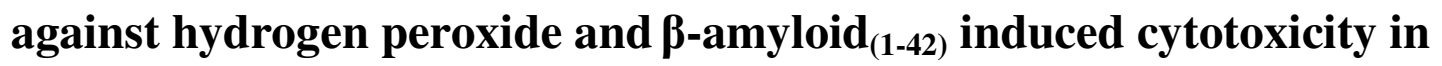 differentiated PC12 cells
}

\begin{abstract}
Short title: Neuroprotective effects of Withania somnifera extract against $\mathrm{H}_{2} \mathrm{O}_{2}$ and $\beta$ amyloid
\end{abstract}

Kumar $S^{1,2}$, Seal $\mathrm{CJ}^{1}$, Howes M-JR ${ }^{3}$, Kite GC ${ }^{3}$ Okello EJ ${ }^{1^{*}}$

${ }^{1}$ Medicinal Plant Research Group, School of Agriculture, Food and Rural Development, Newcastle University, Newcastle upon Tyne, NE1 7RU, UK

${ }^{2}$ University School of Biotechnology, GGS Indraprastha University, Kashmere Gate, Delhi 110403, India

${ }^{3}$ Jodrell Laboratory, Royal Botanic Gardens, Kew, Richmond, Surrey, TW9 3AB

\begin{abstract}
*Medicinal Plant Research Group, School of Agriculture, Food and Rural Development, Newcastle University, Newcastle upon Tyne, NE1 7RU, United Kingdom Phone: +44(0)191 222 5175; Fax: +44(0)191 222 6720; E-mail: e.j.okello@ncl.ac.uk
\end{abstract}




\begin{abstract}
Withania somnifera L. Dunal (Solanaceae), also known as 'ashwagandha' in Sanskrit and as 'Indian ginseng', is widely used in Ayurvedic medicine as a nerve tonic and memory enhancer, with anti-aging, anti-stress, immunomodulatory and antioxidant properties. There is a paucity of data on the potential neuroprotective effects of $W$. somnifera root, as traditionally used, against $\mathrm{H}_{2} \mathrm{O}_{2}$ - and $\mathrm{A} \beta_{(1-42)}$-induced cytotoxicity which are current targets for novel approaches to treat dementia, especially dementia of the Alzheimer's type (AD). In this study, an aqueous extract prepared from the dried roots of $W$. somnifera was assessed for potential protective effects against $\mathrm{H}_{2} \mathrm{O}_{2}$ - and $\mathrm{A} \beta_{(1-42)}$-aggregated fibril cytotoxicity by an MTT assay using a differentiated rat pheochromocytoma PC12 cell line. The results suggest that pre-treatments of differentiated PC12 cells with aqueous extracts of $W$. somnifera root significantly protect differentiated PC12 cells against both $\mathrm{H}_{2} \mathrm{O}_{2}$ - and $\mathrm{A} \beta_{(1-42)}$-induced cytotoxicity, in a concentration dependent manner. To investigate the compounds that could explain the observed effects, the W. somnifera extract was analysed by liquid chromatographyserial mass spectrometry and numerous withanolide derivatives, including withaferin A, were detected. These results demonstrate the neuroprotective properties of an aqueous extract of $W$. somnifera root and may provide some explanation for the putative ethnopharmacological uses of $W$. somnifera for cognitive and other neurodegenerative disorders that are associated with oxidative stress.
\end{abstract}


Keywords: Withania somnifera; neuroprotection; hydrogen peroxide; amyloid; cytotoxicity; Alzheimer's disease

\section{INTRODUCTION}

Alzheimer's disease (AD), the most common form of dementia, is a progressive neurodegenerative disease marked by a decline in cognitive functions, primarily memory loss and language deficit which are often accompanied by behavioural and psychological symptoms such as depression, stress, anxiety and mood disturbances. The pathophysiology of $\mathrm{AD}$ is complex and is characterized by neuronal degeneration (cholinergic neurons in particular), abnormal neurofibrillary tangles, toxic $\beta$-amyloid (A $\beta)$ plaques and deficiencies of neurochemicals which are essential for neuronal transmission (Ros and Poirier, 2004). A $\beta$ cytotoxicity to neuronal cells has been identified as one of the major features in AD pathology, but the exact mechanisms of the cascade of events leading to neurotoxicity still remain unclear (Fukuyama et al., 1994; Fagarasan and Efthimiopoulos, 1996; Yan et al., 1997; Canevari et al., 2004). Some studies suggest that one pathway of $A \beta$ induced cytotoxicity could be mediated by free radicals and oxidative stress (Hensley et al., 1994; Behl, 1994, 1997; Opazo et al., 2000; Canevari et al., 2004). Evidence obtained using cultured cells, such as sympathetic neurons (Greenlund et al., 1995), has demonstrated that reactive oxygen species are produced during the early, but not the late phase of neuronal cell death, suggesting that their production serves as an early signal, rather than a toxic agent, to mediate apoptosis. It has also been demonstrated that $\mathrm{A} \beta$ increases concentrations of hydrogen peroxide $\left(\mathrm{H}_{2} \mathrm{O}_{2}\right)$ in cells (Behl et al., 1994). Hydrogen peroxide is one of the 
typical inducers of apoptosis in neuronal cells (Whittemore et al., 1994; Satoh et al., 1996).

Withania somnifera (L.) Dunal (Solanaceae) root (also known as 'ashwagandha' in Sanskrit and as 'Indian ginseng') is widely used in Ayurvedic medicine (Mishra et al., 2000; Houghton and Howes, 2005) as a nerve tonic and memory enhancer, with antiaging, anti-stress, immunomodulatory and antioxidant properties (Ziauddin et al., 1996; Archana and Namasivayan, 1999, Bhattacharya et al., 2001; Jayaprakasam et al., 2003). Some studies have investigated a pharmacological basis to explain the reputed effects of W. somnifera on cognition, and to assess the therapeutic potential for the steroidal derivatives from this species, particularly the withanolides. Studies in vitro and in vivo have investigated the potential of $W$. somnifera to modulate cholinergic function and extracts of the root, and withanolides isolated from this species (withaferin A, 2,3dihydrowithaferin A and 5 $\beta, 6 \beta$-epoxy-4 $\beta$-hydroxy-1-oxowitha-2,14,24-trienolide), inhibit acetylcholinesterase (Schliebs et al., 1997; Choudhary et al. 2004, 2005; Houghton et al. 2007; Vinutha et al. 2007).

Other studies show that extracts of $W$. somnifera root, and some of the withanolide derivatives in particular, promote dendrite formation in human neuroblastoma cells in vitro in a dose-dependent manner (Tohda et al., 2000; Zhao et al., 2002); withanolide A and withanosides IV and VI extend axons and dendrites, respectively, in vitro (Kuboyama et al., 2002), and withanolide A is considered to reconstruct neuronal networks in vivo (Kuboyama et al., 2005). In an animal model of dementia and spinal cord injury, withanolide A, withanoside IV, and withanoside VI restored presynapses and postsynapses (Tohda et al., 2000, 2005). Other studies have investigated various $W$. somnifera extracts in vivo to explain the putative effects of $W$. somnifera, including 
potential neuroprotection against various models of oxidative stress and cytotoxicity, and disease mechanisms have been explored, with varying results (Parihar and Hemnani, 2003; Sankar et al., 2007; Bhatnagar et al., 2009). Root extracts from this species have also been shown to significantly reduce the number of hippocampal degenerating cells in the brains of stressed rodents (Jain et al., 2001) and were neuroprotective in animal models of Parkinson's disease (Ahmad et al., 2005; Sankar et al., 2007) and Huntington disease (Kumar and Kumar, 2009). Although some in vivo studies using various animal models suggest $W$. somnifera extracts can improve antioxidant status and provide neuroprotection (Jain et al., 2001; Parihar and Hemnani, 2003; Sankar et al., 2007; Bhatnagar et al., 2009), there is a paucity of data on the potential protective effects of $W$. somnifera root, as traditionally used, against $\mathrm{H}_{2} \mathrm{O}_{2}$ and $\mathrm{A} \beta_{(1-42)}$-induced cytotoxicity which are current targets for novel approaches for the treatment of dementia, especially dementia of the Alzheimer's type (AD). The aim of this study was to investigate the potential neuroprotective effects of an aqueous extract of $W$. somnifera root against $\mathrm{H}_{2} \mathrm{O}_{2}$ - and $\mathrm{A} \beta_{(1-42)}$-induced toxicity under in vitro conditions using a differentiated PC12 cell line as a model of neuronal cells.

\section{MATERIALS AND METHODS}

Plant material. The roots of $W$. somnifera were purchased from a local herbalist in India and were verified and authenticated by Dr George Wake, School of Biology, Newcastle University, UK. A voucher specimen (SK-WS-01) is deposited in the Herbarium of the Medicinal Plant Research Group, Newcastle University, UK. 
Extract preparation. The air dried roots were ground to powder consistency using an electric grinder. $1 \mathrm{~g}$ of powdered root was infused in freshly boiled de-ionised water $(1: 50 \mathrm{w} / \mathrm{v})$ for $25 \mathrm{~min}$. The infusion was left to cool to room temperature and centrifuged (12000 rpm, $15 \mathrm{~min})$. The supernatant was re-centrifuged (12000 rpm, 10 $\min$ ) and then freeze dried. The freeze dried aliquots were reconstituted in de-ionised water prior to assay.

Cell line and cell culture. Rat pheochromocytoma (PC12) cell line was a generous gift from the Medical School, Newcastle University. RPMI-1640, penicillin-streptomycin, foetal calf serum, glutamine and nerve growth factor (NGF) were purchased from Invitrogen (UK). A $\beta_{(1-42)}$ and trypan blue were purchased from Sigma (UK).

Cells were maintained in RPMI media supplemented with $10 \%$ heat-inactivated foetal bovine serum, $2 \mathrm{mM}$ L-glutamine, $100 \mathrm{IU} / \mathrm{ml}$ penicillin-streptomycin in humidified $5 \%$ $\mathrm{CO}_{2}$ and $95 \%$ air at $37{ }^{\circ} \mathrm{C}$. All cells were cultured in culture flasks pre-coated with poly-D-lysine $(0.1 \mathrm{mg} / \mathrm{mL})$. Cells were differentiated for 2-3 days using $50 \mathrm{ng} / \mathrm{mL}$ NGF. Prior to experimental treatments, cells were microscopically examined to assess differentiation. Eighty percent or more of cells with neurite outgrowth extensions over 2-3-fold cell body size were considered to be differentiated PC12 cells (dPC12). The medium was changed every alternate day. Prior to confluence, cells were dislodged by mechanical scraping and split in 1:3 ratio. Before each experiment, cells were checked for viability using a trypan blue $(0.5 \%)$ dye exclusion method (Freshney, 2000). Cells were counted using a haemocytometer and the density was adjusted to $1 \times 10^{5}$ cells $/ \mathrm{mL}$ prior to plating in 96-well plates; cells in exponential growth phase were used. 
Assay of $\mathrm{H}_{2} \mathrm{O}_{2}$-induced toxicity. Before treatment, cells were plated at an appropriate density $\left(1 \times 10^{4}\right.$ cells $\left./ 100 \mu \mathrm{L}\right)$ in a 96 -well plate and incubated for $24 \mathrm{~h}$ at $37{ }^{\circ} \mathrm{C}$, so that the cells were acclimatized to the new environment. Cells were pre-incubated with $W$. somnifera root extract (concentration range: $0.097-50 \mu \mathrm{g} / \mathrm{mL}$ ), prior to exposure to $\mathrm{H}_{2} \mathrm{O}_{2}$ (concentration range: $12.5 \mu \mathrm{M}-400 \mu \mathrm{M}$ ) from a freshly prepared $1000 \mu \mathrm{M}$ stock solution. After $24 \mathrm{~h}$ the cell viability was determined by an MTT assay, as described below.

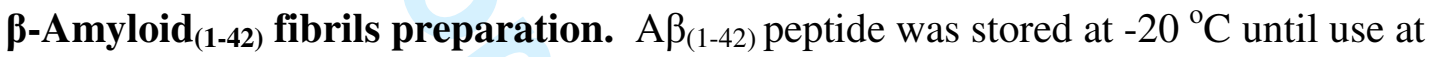
room temperature; lyophilized peptide was dissolved in distilled water at a concentration of $0.1 \mathrm{mg} / \mathrm{mL}$, with thorough pipetting over a period of 2 min to clarify the solution. It was then incubated overnight at $37{ }^{\circ} \mathrm{C}$ with constant oscillation to form the fibrils used to induce toxicity in dPC12 cells.

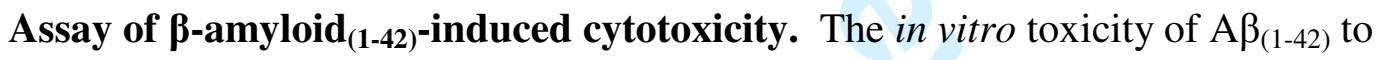 \\ $\mathrm{dPC} 12$ cells was measured by incubating the cells for $24 \mathrm{~h}$ at $37^{\circ} \mathrm{C}$, with increasing \\ concentrations $(0.007-2 \mu \mathrm{g} / \mathrm{mL})$ of aggregated $\mathrm{A} \beta_{(1-42)}$ peptide in a 96-well plate. Cell \\ viability was then assessed by measuring cellular redox activity with the MTT assay \\ described below.
}

MTT assay. PC12 cell viability was determined by the MTT reduction assay. In brief, MTT, a tetrazolium salt, is cleaved to formazan by succinate dehydrogenase, an enzyme in the mitochondrial respiratory chain, by live cells. After pre-incubation of the dPC12 cells with the test extracts and toxicity inducers $\left(\mathrm{H}_{2} \mathrm{O}_{2}\right.$ or $\left.\mathrm{A} \beta\right)$ for $24 \mathrm{~h}$, cells were 
incubated with MTT $(0.5 \mathrm{mg} / \mathrm{mL})$ for $3 \mathrm{~h}$. The dark blue formazan crystals formed in live cells were solubilised with dimethylsulfoxide and ethanol (1:1) and the absorbance was measured at $570 \mathrm{~nm}$ using a spectrophotometer (Molecular Device Spectramax Plus 384, equipped with Softmax Pro V5 software) (Mosmann, 1983).

Liquid chromatography-serial mass spectrometry. The freeze dried aqueous extract of W. somnifera root was analysed by liquid chromatography-serial mass spectrometry $\left(\right.$ LC-MS $^{\mathrm{n}}$ ) using an HPLC system (Thermo Scientific 'Surveyor' autosampler, pumps and diode array detector) coupled to a 3D ion-trap mass spectrometer (Thermo Scientific 'LCQ Classic') via an electrospray source. Chromatography was achieved on a $150 \mathrm{~mm}$ x $4.6 \mathrm{~mm}, 5$ m C18 column (Phenomenex 'Luna C18(2)') using a $1 \mathrm{ml} / \mathrm{min}$ mobile phase gradient of $10 \%$ to $100 \%$ aqueous acetonitrile containing $0.1 \%$ formic acid over $40 \mathrm{~min}$. The flow to the ESI source was reduced to $200 \mu \mathrm{l} / \mathrm{min}$ by a splitter and the source was operated using a needle voltage of $\pm 4.2 \mathrm{kV}$ and desolvation nitrogen gas flows of 80 (sheath) and 20 (auxillary) units. The heated capillary temperature was $220^{\circ} \mathrm{C}$ and standard tuning voltages (obtained from rutin) were used. The instrument was operated using Xcalibur 2.0 software and components in the LC-MS ${ }^{\mathrm{n}}$ analyses were detected using MassFrontier 4.0 (both Thermo Scientific). Withaferin A (LGC Standards, UK) was also subjected to LC-MS ${ }^{\mathrm{n}}$ analysis using this method.

\footnotetext{
Statistical analyses. Results are expressed as the mean \pm SEM. Student t-test was used to compare differences between test groups and the negative control $\left(\mathrm{H}_{2} \mathrm{O}_{2}\right.$ or $\mathrm{A} \beta$ only) using Graphpad statistical software; $\mathrm{p}<0.05$ were considered significant.
} 


\section{RESULTS}

\section{Effect of $\mathrm{H}_{2} \mathrm{O}_{2}$ on dPC12 cell viability after treatment for 24, 48 and $72 \mathrm{~h}$}

When dPC12 cells were incubated with different $\mathrm{H}_{2} \mathrm{O}_{2}$ concentrations $(12.5 \mu \mathrm{M}$ to 400 $\mu \mathrm{M})$ at $24,48,72 \mathrm{~h}$ time intervals, a concentration-dependent cytotoxicity was observed (Fig. 1). The cell viability was decreased to $50 \%$ at $200 \mu \mathrm{M} \mathrm{H}_{2} \mathrm{O}_{2}$ during 24 incubation, but less than $50 \%$ for 48 and $72 \mathrm{~h}$ incubation at 200 and $400 \mu \mathrm{M} \mathrm{H}_{2} \mathrm{O}_{2}$ ( $\mathrm{p}<0.001$ ). Thus, $200 \mu \mathrm{M} \mathrm{H}_{2} \mathrm{O}_{2}$ was selected as an appropriate concentration to induce toxicity, with an incubation time of $24 \mathrm{~h}$, to assess the effects of the $W$. somnifera extract in further experiments.

\section{Effect of W. somnifera extract on viability of dPC12 cells against $\mathrm{H}_{2} \mathrm{O}_{2}$-induced cytotoxicity}

As shown in Fig. 2, the aqueous extract of W. somnifera significantly protected dPC12 cells from $\mathrm{H}_{2} \mathrm{O}_{2}$-induced toxicity when cells were pre-incubated with $W$. somnifera extract for $24 \mathrm{~h}$ prior to $\mathrm{H}_{2} \mathrm{O}_{2}(200 \mu \mathrm{M})$ exposure. After $\mathrm{H}_{2} \mathrm{O}_{2}$ exposure for $24 \mathrm{~h}, 50-80$ $\%$ cell viability was observed at extract concentrations from $6.11 \mu \mathrm{g} / \mathrm{mL}$ to $100 \mu \mathrm{g} / \mathrm{mL}$, compared with the negative control $\left(\mathrm{H}_{2} \mathrm{O}_{2}\right.$ alone), with 50 and $100 \mu \mathrm{g} / \mathrm{mL}$ extract concentrations showing the greatest improvement compared with the negative control $(\mathrm{p}<0.001)$. At the highest extract concentration $(200 \mu \mathrm{g} / \mathrm{mL})$ the cytoprotective effects were abolished, due, perhaps, to direct cytotoxic and antiproliferative properties of $W$. somnifera being expressed at high concentrations (Sabbaraju et al., 2006; Stan et al., 2008). 


\title{
Effect of $\beta$-amyloid $(1-42)$-peptide aggregates on dPC12 cells
}

\begin{abstract}
. A concentration-dependent decrease of cell survival was observed after exposure to A $\beta$ (1-42) over the concentration range of 0.007 to $2.0 \mu \mathrm{g} / \mathrm{mL}$ (Fig. 3). The cell survival was expressed as a percentage of the control measured in the absence of $A \beta$ peptide. The cell viability was decreased to approximately $50 \%$ at $0.5 \mu \mathrm{g} / \mathrm{mL}$ and no further decrease was observed by increasing the $\mathrm{A} \beta$ concentration above $0.5 \mu \mathrm{g} / \mathrm{mL}$. Consequently, this concentration of $\mathrm{A} \beta$ was selected to induce cytotoxicity in further experiments to investigate the neuroprotective effect of $W$. somnifera extract against A $\beta$-induced toxicity.
\end{abstract}

\section{Effect of $W$. somnifera extract on viability of dPC12 cells against $\beta$-amyloid d1-42)- $^{-}$ induced toxicity}

The pre-treatment of $W$. somnifera extract $(0.75 \mu \mathrm{g} / \mathrm{mL}-100 \mu \mathrm{g} / \mathrm{mL})$ for $24 \mathrm{~h}$ prior to $\mathrm{A} \beta$ incubation produced dose-dependent attenuation of $\mathrm{A} \beta$-induced toxicity in dPC12 cells. Maximum viability ( $80 \%$ of positive control) was observed at the highest concentration (100 $\mu \mathrm{g} / \mathrm{mL})$ tested (Fig. 4).

\section{$\mathrm{LC}_{-M S}{ }^{\mathrm{n}}$ analysis}

Positive ion LC-MS ${ }^{\mathrm{n}}$ analysis of the W. somnifera extract revealed numerous components (Fig. 5). Component $\mathbf{3 6}$ was identified as withaferin A against a standard and together with two other isomeric withanolides $(\mathbf{3 8} \& \mathbf{4 0})$, these constituted the main withanolide aglycones in the extract. The majority of the other components, eluting earlier in the analysis, were assigned as derivatives of withanolides (Table 1). Among these were compounds clearly assignable as glycosides of withanolides $(\mathbf{1 0}, \mathbf{2 1}, \mathbf{2 2}, \mathbf{2 5}$, 
27, 29, 30, 33 \& 35) since, following MS2 of the protonated or ammoniated molecules, they generated fragment ions resulting from cleavage of glycosidic bonds, including protonated aglycone ions at $\mathrm{m} / \mathrm{z}$ values expected for reported withanolides. Furthermore, upon MS3 analysis, these protonated aglycone ions showed patterns of neutral losses similar to those observed following MS2 analysis of the free withanolides in the extract. More exact assignment of withanolides from $W$. somnifera was not determined due to the numerous isomeric forms of withanolides reported in the literature (CCD, 2010). Other components were also assigned as withanolide derivatives. Following MS2 of the protonated molecule they generated a complex array of product ions, but among these were those with expected $\mathrm{m} / \mathrm{z}$ values for fragments corresponding to protonated withanolide aglycones. Furthermore, for components such as $\mathbf{1 4}$ that generated a product ion $\mathrm{m} / \mathrm{z} 471$ (the value expected for a fragment equivalent to protonated withaferin A and isomers), other product ions at $\mathrm{m} / \mathrm{z} 299$ and 281 were also observed; withaferin A also generated abundant product ions at these $\mathrm{m} / \mathrm{z}$ values following MS/MS of the protonated molecule. Several of the components assigned as withanolide derivatives appeared to have odd-number molecular masses (i.e. suggesting they contained an odd number of nitrogen atoms), including component $\mathbf{1 2}$ that produced the largest chromatographic peak in the analysis. The major ion species generated by positive ESI of $12(\mathrm{~m} / \mathrm{z} 778)$ was assigned as $[\mathrm{M}+\mathrm{H}]^{+}$on the basis of minor confirmatory ions at $m / z 795\left[\mathrm{M}+\mathrm{NH}_{4}\right]^{+}$and $m / z 800[\mathrm{M}+\mathrm{Na}]^{+}$, and the generation of a major ion species at $m / z, 776[\mathrm{M}-\mathrm{H}]^{-}$in a negative ion ESI analysis. The MS2 spectrum of protonated 12 showed minor product ions at $m / z, 471,299$ and 281, suggesting that the compound contained a withanolide moiety. The major product ion was at $m / z 649$ and MS3 analysis of this ion produced a spectrum that was almost 
identical to the product ion spectrum of protonated $6\left([\mathrm{M}+\mathrm{H}]^{+}=m / \mathrm{z} 649\right)$. Although nitrogen-containing compounds (including withanamides that protect PC12 cells from A $\beta$ (Jayaprakasam et al., 2009)) have been reported in the fruits of W. somnifera, none have the same molecular mass as $\mathbf{1 2}$ and do not display a potential aglycone product ion at $m / z 471$ (Jayaprakasam et al., 2004). An isomer of 12, component 16, also generated a major product ion at $m / z 649$, but serial MS analysis of this ion produced a different spectrum to that of $\mathbf{1 2}$, in particular the spectrum suggested that the molecular mass of the aglycone was 452 . Components $\mathbf{1 3}$ and $\mathbf{1 7}$ were likely hexosides of $\mathbf{1 2}$ (or its isomers) and a likely hexoside of $\mathbf{1 4}$ (or isomer) was also present (component 15). Four components $(\mathbf{3 9}, \mathbf{4 1}, \mathbf{4 2} \& \mathbf{4 4})$ in the $\mathrm{LC}-\mathrm{MS}^{\mathrm{n}}$ analysis were assigned as withanolide sulphates as their molecular masses showed an 80 Da increment over that of known withanolides. Other noted components in the extract were low molecular mass nitrogen containing compounds (1-3).

\section{DISCUSSION}

There is growing interest in naturally-derived bioactive compounds with potential neuroprotective properties against a range of neurodegenerative diseases. One area of current pharmacological focus is neuroprotective therapeutic strategies aimed at counteracting $\mathrm{H}_{2} \mathrm{O}_{2}$ - and $\mathrm{A} \beta$-induced neurotoxicity associated with $\mathrm{AD}$ pathophysiology. In this study, PC12 cells were used as an in vitro model to study the neuroprotective potential of W. somnifera root aqueous extract against $\mathrm{H}_{2} \mathrm{O}_{2}$ - and $\mathrm{A} \beta$ induced toxicity. PC12 cells were chosen as they acquire neuronal like projections when induced to differentiate with nerve growth factor. The differentiated PC12 cells are both morphologically and physiologically very similar to living neurons in the brain; 
therefore the results obtained by neuroprotective studies with experimental test plant extracts will be more likely to represent the response when using differentiated, rather than with non-differentiated cells (Datki et al., 2003). To induce A $\beta$ peptide toxicity, the peptide fragment with a length of 1-42 amino acid residues was used, as this fragment aggregates very rapidly and is responsible for inducing toxicity as compared with nonaggregated peptides. The toxic effects of $A \beta_{(1-42)}$ fragments have been well-documented in a number of studies (Behl et al., 1992; Michaelis et al., 1998; Limpeanchob et al., 2008).

The present study demonstrated that pre-treatments of differentiated PC12 cells with an aqueous extract of $W$. somnifera root significantly protected dPC12 cells against both $\mathrm{H}_{2} \mathrm{O}_{2-}$ and $\mathrm{A} \beta$-induced cytotoxicity, in a concentration dependent manner. $\mathrm{As} A \beta$ is known to increase free radical production and lipid peroxidation in PC12 cells, leading to apoptosis and cell death (Jung et al., 2007), the cytoprotective effects observed could be attributed to the presence of free radical scavenging compounds in the aqueous extract of $W$. somnifera. Evidence to support this mode of action has been shown previously. Inhibition of lipid peroxidation due to an antioxidant action has been observed both in vitro and in vivo with extracts of $W$. somnifera root and some of the component withanolides, including withaferin A (Dhuley, 1998; Panda et al., 1997; Bhattacharya et al., 2000; Chaurasia et al., 2000), a compound detected in the $W$. somnifera extract investigated in the present study. In addition to the withanolides having antioxidant capacity and decreasing lipid peroxidation in rodent brains, withanolides also enhanced catalase and glutathione peroxidase activities in rat frontal cortex and striatum (Chaurasia et al., 2000; Mishra et al., 2000; Scartezzini and Speroni, 2000; Bhattacharya et al., 1997 and 2001; Subbaraju et al., 2006). In another 
study, an extract of $W$. somnifera was associated with attenuation of memory loss induced by oxidative stress mediated by free radicals in an animal model (Parihar et al., 2004). W. somnifera root extract was also shown to significantly reduce the level of lipid peroxidation and improved the antioxidant status in an animal model of Parkinson's disease (Sankar et al., 2007). Other studies showed that W. somnifera root extract also imparted neuroprotective effects, observed in a 6-hydroxydopamineinduced model in rats, and a lithium-pilocarpine induced seizures model of status epilepticus in rats (Kulkarni et al., 1998) and various other animal models of neurological disorders, including Parkinsonism and epilepsy (Sanker et al., 2007; Kulkarni and Dhir, 2008). There is also evidence of neuroprotection by withanolide A, withanoside IV, and withanoside VI, steroidal derivatives isolated from a root extract of W. somnifera, that attenuated $\mathrm{A} \beta$ (25-35)-induced axonal, dendritic and synaptic losses and memory deficits in mice (Tohda et al., 2005; Kuboyama et al., 2005; Kuboyama et al., 2006). A study by Jayaprakasam et al. (2009) demonstrated the ability of withanamides A and C present in W. somnifera fruit extracts to protect undifferentiated PC-12 cells from A $\beta$ cytotoxicity. Thus, the neuroprotective effects of the $W$. somnifera aqueous root extract against $\mathrm{H}_{2} \mathrm{O}_{2}$ - and $\mathrm{A} \beta$-induced cytotoxicity shown in this study, are consistent with other studies that have suggested W. somnifera may be neuroprotective in vivo by mediating antioxidant effects.

One in vitro study showed an interesting finding in which $W$. somnifera root extract significantly and dose-dependently increased the percentage of cells with neurites in human neuroblastoma SK-N-SH cells (Tohda et al., 2000). However, one observation in our study was that at high concentrations $(>100 \mu \mathrm{g} / \mathrm{mL})$, the aqueous extract exhibited cytotoxic and perhaps anti-proliferative properties against the $\mathrm{dPC} 12$ cell line, 
in line with reputed anticancer properties of W. somnifera (Subbaraju et al., 2006; Stan et al., 2008). Indeed, component 32, detected in the W. somnifera extract by LC-MS ${ }^{\mathrm{n}}$ analysis (Table 1, Fig. 5), showed mass spectral data consistent with the dimeric thiowithanolide, ashwagandhanolide, a compound reported to inhibit cell proliferation in various tumor cell lines (Subbaraju et al., 2006).

In conclusion, this study demonstrated that an aqueous extract of W. somnifera root, in which numerous withanolide derivatives were detected, was neuroprotective against $\mathrm{H}_{2} \mathrm{O}_{2}$ - and $\mathrm{A} \beta$-induced cytotoxicity, providing further evidence to explain the use of $W$. somnifera root in some cognitive disorders. However, further investigations are required to confirm the identity and potency of the specific compounds responsible for the reported neuroprotective effects of $W$. somnifera against $\mathrm{H}_{2} \mathrm{O}_{2}$ - and $\mathrm{A} \beta$-induced cytotoxicity, and to determine whether the observed neuroprotective effects are due to potential polyvalent activities (Williamson, 2001) amongst the constituents of the withanolide-rich aqueous extract.

\section{REFERENCES}

Ahmad M, Saleem S, Ahmad AS, Ansari MA, Yousuf S, Hoda MN, Islam F. 2005.

Neuroprotective effects of Withania somnifera on 6-hydroxydopamine induced

Parkinsonism in rats. Human Exp Toxicol 24: 137-147.

Bhatnagar M, Sharma D, Salvi M. 2009. Neuroprotective effects of Withania somnifera Dunal.: A possible mechanism. Neurochem Res 34: 1975-1983. 


\begin{abstract}
Bhattacharya A, Ghosal S, Bhattacharya SK. 2001. Anti-oxidant effect of Withania somnifera glycowithanolides in chronic footshock stress-induced perturbations of oxidative free radical scavenging enzymes and lipid peroxidation in rat frontal cortex and striatum. J Ethnopharmacol 74: 1-6.

Bhattacharya A, Ramanathan M, Ghosal S, Bhattacharya SK. 2000. Effect of Withania somnifera glycowithanolides on iron-induced hepatotoxicity in rats. Phytother Res 14: $568-570$.
\end{abstract}

Bhattacharya SK, Satyan KS, Ghosal S. 1997. Antioxidant activity of glycowithanolides from Withania somnifera. Ind J Exp Biol 35: 236-239.

CCD (Combined Chemical Dictionary 11.2). 2010. http://ccd.chemnetbase.com. Taylor and Francis Group

Chaurasia SS, Panda S, Kar A. 2000. Withania somnifera root extract in the regulation of lead-induced oxidative damage in male mouse. Pharmacol Res 41: 663-666.

Choudhary MI, Nawaz SA, Zaheer-ul-Haq, Lodhi MA, Ghayur MN, Jalil S, Riaz N, Yousuf S, Malik A, Gilani AH, Atta-ur-Rahman. 2005. Withanolides, a new class of natural cholinesterase inhibitors with calcium antagonistic properties. Biochem Biophys Res Comm 334: 276-287.

Choudhary MI, Yousuf S, Nawaz SA, Ahmed S, Atta-ur-Rahman. 2004. Cholinesterase inhibiting withanolides from Withania somnifera. Chem Pharm Bull 52: 1358-1361. Dhuley JN. 2001. Nootropic-like effect of ashwagandha (Withania somnifera L.) in mice. Phytother Res 15: 524-528.

Dhuley JN. 1998. Effect of ashwagandha on lipid peroxidation in stress-induced animals. J Ethnopharmacol 60: 173-178. 
Houghton PJ, Howes M-JR. 2005. Natural products and derivatives affecting neurotransmission relevant to Alzheimer's and Parkinson's disease. Neurosignals 14: 622.

Houghton PJ, Howes M-JR, Lee CC, Steventon G. 2007. Uses and abuses of in vitro tests in ethnopharmacology: Visualizing an elephant. J Ethnopharmacol 110: 391-400. Jain S, Shukla SD, Sharma K, Bhatnagar M. 2001. Neuroprotective effects of Withania somnifera Dunn. in hippocampal sub-regions of female albino rat. Phytother Res 15: 544-548.

Jayaprakasam B, Zhang Y, Seeram NP, Nair MG. 2003. Growth inhibition of human tumor cell lines by withanolides from Withania somnifera leaves. Life Sciences 74: 125132.

Jayaprakasam B, Strasburg GA, Nair MG. 2004. Potent lipid peroxidation inhibitors from Withania somnifera fruits. Tetrahedron 60: 3109-3121.

Jayaprakasam B, Padmanabhan K, Nair MG. 2009. Withanamides in Withania somnifera fruit protect PC-12 cells from beta-amyloid responsible for Alzheimer's disease. Phytother Res Dec2. [Epub ahead of print].

Kuboyama T, Tohda C, Zhao J, Nakamura N, Hattori M, Komatsu K. 2002. Axon- or dendrite-predominant outgrowth induced by constituents from Ashwagandha. NeuroReport 13: 1715-1720.

Kuboyama T, Tohda C, Komatsu K. 2005. Neuritic regeneration and synaptic reconstruction induced by withanolide A. Br J Pharmacol 144: 961-971.

Kuboyama T, Tohda C, Komatsu K. 2006. Withanoside IV and its active metabolite, sominone, attenuate Abeta (25-35)-induced neurodegeneration. Eur J Neurosci 23:1417-1426. 
Kumar P, Kumar A. 2009. Possible neuroprotective effect of Withania somnifera root extract against 3-nitropropionic acid-induced behavioral, biochemical, and mitochondrial dysfunction in an animal model of Huntington's disease. J Med Food 12: 591-600.

Mishra L, Singh BB, Dagenais S. 2000. Scientific basis for the therapeutic use of Withania somnifera (ashwagandha): A review. Altern Med Rev 5: 334-346.

Panda S, Gupta P, Kar A. 1997. Protective role of ashwagandha in cadmiuminduced hepatotoxicity and nephrotoxicity in male mouse. Curr Sci 72: 546-547. Parihar MS, Hemnani T. 2003. Phenolic antioxidants attenuate hippocampal neuronal cell damage against kainic acid induced excitotoxicity. J Biosci 28: 121-128.

Sankar SR, Manivasagam T, Krisnamurti, Ramanathan M. 2007. The neuroprotective effect of Withania somnifera root extract in MPTP-intoxicated mice: An analysis of behavioural and biochemical variables. Cell Mol Biol Lett 12: 473-481.

Scartezzini P, Speroni E. 2000. Review on some plants of Indian traditional medicine with antioxidant activity. $J$ Ethnopharmacol 71: 23-43.

Stan SD, Zeng Y, Singh SV. 2008. Ayurvedic medicine constituent withaferin A causes G2 and M phase cell cycle arrest in human breast cancer cells. Nutr Cancer 60 (Suppl. 1): 51-60.

Subbaraju GV, Vanisree M, Rao CV, Sivaramakrishna C, Sridhar P, Jayaprakasam B, Nair MG. 2006. Ashwagandhanolide, a bioactive dimeric thiowithanolide isolated from the roots of Withania somnifera. J Nat Prod 69: 1790-1792.

Tohda C, Kuboyama T, Komatsu K. 2000. Dendrite extension by methanol extract of Ashwagandha (roots of Withania somnifera) in SK-N-SH cells. NeuroReport 11: 19811985. 
Vinutha B, Prashanth D, Salma K, Sreeja SL, Pratiti D, Padmaja R, Radhika S, Amit A, Venkateshwarlu K, Deepak M. 2007. Screening of selected Indian medicinal plants for acetylcholinesterase inhibitory activity. J Ethnopharmacol 109: 359-363.

Williamson EM. 2001. Synergy and other interactions in phytomedicines.

Phytomedicine 8: 401-409.

Zhao J, Nakamura N, Hattori M, Kuboyama T, Tohda C, Komatsu K. 2002.

Withanolide derivatives from the roots of Withania somnifera and their neurite outgrowth activities. Chem Pharm Bull 50: 760-765.

\section{Figures legends}

Fig. 1 Concentration-dependent inhibition of cell viability by $\mathrm{H}_{2} \mathrm{O}_{2}$ in differentiated PC12 cells after treatment for 24, 48 and $72 \mathrm{hr}$. Values are expressed as a percentage of control values. C: untreated control. Data are presented as the mean \pm SEM of three separate experiments performed in triplicate. $* \mathrm{p}<0.05, * * \mathrm{p}<0.01$ and $* * * \mathrm{p}<0.001$ compared with the untreated control. $\square 24 \mathrm{~h} \square 48 \mathrm{~h} \square 72 \mathrm{~h}$

Fig. 2 Protective effect of an aqueous extract of W. somnifera against $\mathrm{H}_{2} \mathrm{O}_{2}$-induced cytotoxicity in differentiated PC12 cells. NC: negative control $\left(\mathrm{H}_{2} \mathrm{O}_{2}\right.$ alone, $\left.200 \mu \mathrm{M}\right)$; PC: positive control $\left(\mathrm{H}_{2} \mathrm{O}_{2}\right.$ absent). Values are expressed as a percentage of control (PC) values. Data are presented as mean \pm SEM of three separate experiments 
performed in triplicates. ${ }^{*} \mathrm{p}<0.05,{ }^{*} \mathrm{p}<0.01$ and $* * * \mathrm{p}<0.001$, compared with negative control. The protective effect of $W$. somnifera against $\mathrm{H}_{2} \mathrm{O}_{2}$-induced cytotoxicity was evaluated after $24 \mathrm{hr}$ incubation time.

Fig. 3 Dose-dependent neurotoxicity of $A \beta_{(1-42)}$ aggregates in differentiated PC12 cells measured by an MTT assay (incubation time: $24 \mathrm{hr}$ ). Values are expressed as a percentage of control values. C: untreated control. Data are presented as the mean \pm SEM of three separate experiments performed in triplicate. ${ }^{*} \mathrm{p}<0.05$, $* * \mathrm{p}<0.01$ and $* * * \mathrm{p}<0.001$, compared with control.

Fig. 4 Protective effect of W. somnifera extract against $A \beta_{(1-42)}$-induced toxicity in differentiated PC12 cells. NC: negative control (A $\beta$ only, $0.5 \mu \mathrm{g} / \mathrm{mL})$; PC: positive control (A $\beta$ absent). Values are expressed as a percentage of control (PC) values. Data are presented as the mean \pm SEM of three separate experiments performed in triplicate. ${ }^{*} \mathrm{p}<0.05, * * \mathrm{p}<0.01$ and $* * * \mathrm{p}<0.001$, compared with negative control. The protective effect of $W$. somnifera against $\mathrm{A} \beta_{(1-42)}$ induced cytotoxicity was evaluated after $24 \mathrm{hr}$ incubation time.

Fig. 5 MS1 base ion chromatogram from LC-MS ${ }^{\mathrm{n}}$ (positive ESI) analysis of $W$. somnifera root aqueous extract. Peaks are assigned to withanolides, as presented in Table 1; compound $\mathbf{3 6}$ is assigned as withaferin A by comparison with a reference standard of withaferin A. 
Table 1. Compounds observed by LC-MS analysis of $W$. somnifera root aqueous extract. Data presented are the retention time (min), the major ion species found in positive and negative modes (and the assignment of these ions), the deduced molecular mass ( $\left.\mathrm{M}_{\mathrm{r}}\right)$ and the suggested molecular mass of the aglycone (A) determined from the positive and / or negative ion MS2 spectra.

\begin{tabular}{|c|c|c|c|c|c|c|c|c|c|}
\hline Compound & $\begin{array}{r}\text { Retention } \\
\text { time } \\
(\mathrm{min}) \\
\end{array}$ & $\begin{array}{l}\text { Positive } \\
\text { ion }(m / z)\end{array}$ & Assignment & $\begin{array}{l}\text { Negative } \\
\text { ion }(m / z)\end{array}$ & Assignment & $\mathbf{M}_{\mathbf{r}}$ & $\mathbf{A}$ & Assignment & $\begin{array}{l}\text { Product ions following MS2 of positive ion species listed } \\
(\mathrm{m} / z ; \%)\end{array}$ \\
\hline 1 & 7.4 & 224 & {$[\mathrm{M}+\mathrm{H}]+$} & - & - & 223 & NA & - & $124(100) 93(17)$ \\
\hline 2 & 7.8 & 226 & {$[\mathrm{M}+\mathrm{H}]+$} & - & - & 225 & NA & - & $124(100) 93(20)$ \\
\hline 3 & 8.9 & 226 & {$[\mathrm{M}+\mathrm{H}]+$} & - & - & 225 & NA & - & $126(100) 84(43)$ \\
\hline 4 & 9.1 & 794 & {$[\mathrm{M}+\mathrm{H}]+$} & 792 & {$[\mathrm{M}-\mathrm{H}]-$} & 793 & - & - & $776(10) 655$ (100) 648 (55) \\
\hline 5 & 9.9 & 574 & {$[\mathrm{M}+\mathrm{H}]+$} & 572 & {$[\mathrm{M}-\mathrm{H}]-$} & 573 & - & - & $556(100) 538(85) 472(90)$ \\
\hline 6 & 10.1 & 649 & {$[\mathrm{M}+\mathrm{H}]+$} & 647 & {$[\mathrm{M}-\mathrm{H}]-$} & 648 & 470 & withanolide derivative & 632 (100) 556 (40) 471 (57) 299 (17) 281 (7) \\
\hline 7 & 10.2 & 1112 & - & - & - & & - & - & unstable ion \\
\hline 8 & 10.6 & 832 & {$\left[\mathrm{M}+\mathrm{NH}_{4}\right]+$} & 859 & $\mathrm{HCOO}]-$ & 814 & 472 & withanolide glycoside & $815(5) 635(7) 473(100)$ \\
\hline 9 & 11.0 & 794 & {$[\mathrm{M}+\mathrm{H}]+$} & 792 & {$[\mathrm{M}-\mathrm{H}]-$} & 793 & 520 & withanolide derivative & $665(100) 521(80)$ \\
\hline 10 & 11.1 & 962 & {$\left[\mathrm{M}+\mathrm{NH}_{4}\right]+$} & 943 & {$[\mathrm{M}-\mathrm{H}]-$} & 944 & 458 & withanolide trihexoside & 945 (916) $983(30) 621(100) 459(95)$ \\
\hline $\begin{array}{l}11 \\
12\end{array}$ & $\begin{array}{l}11.3 \\
11.5\end{array}$ & $\begin{array}{l}592 \\
778\end{array}$ & $\begin{array}{l}{[\mathrm{M}+\mathrm{H}]+} \\
{[\mathrm{M}+\mathrm{H}]+}\end{array}$ & $\begin{array}{l}590 \\
776\end{array}$ & $\begin{array}{l}{[\mathrm{M}-\mathrm{H}]-} \\
{[\mathrm{M}-\mathrm{H}]-}\end{array}$ & $\begin{array}{l}591 \\
777\end{array}$ & $\begin{array}{l}470 \\
470\end{array}$ & $\begin{array}{l}\text { withanolide derivative } \\
\text { withanolide derivative }\end{array}$ & $\begin{array}{l}575(80) 574(100) 471(35) 435(20) 299(30) 281(20) \\
760(10) 649(100) 632(55) 556(20) 471(22) 299(9) 281 \\
(4)\end{array}$ \\
\hline 13 & 11.6 & 940 & {$[\mathrm{M}+\mathrm{H}]+$} & 938 & {$[\mathrm{M}-\mathrm{H}]-$} & 939 & 470 & withanolide derivative & $922(70) 886(68) 865(86) 649$ (100) 471 (16) \\
\hline 14 & 11.8 & 721 & {$[\mathrm{M}+\mathrm{H}]+$} & 719 & {$[\mathrm{M}-\mathrm{H}]-$} & 720 & 470 & withanolide derivate & 703 (16) 592 (100) 574 (41) 471 (17) 299 (12) 281 910) \\
\hline 15 & 11.9 & 883 & {$[\mathrm{M}+\mathrm{H}]+$} & 881 & {$[\mathrm{M}-\mathrm{H}]-$} & 882 & - & withanolide derivative & 865 (91) 847 (71) 829 (100) 799 (47) 592 (20) \\
\hline 16 & 12.1 & 778 & {$[\mathrm{M}+\mathrm{H}]+$} & 776 & {$[\mathrm{M}-\mathrm{H}]-$} & 777 & 452 & withanolide derivative & 760 (7) 649 (100) 632 (64) 556 (18) 453 (15) \\
\hline 17 & 12.2 & 940 & {$[\mathrm{M}+\mathrm{H}]+$} & 938 & {$[\mathrm{M}-\mathrm{H}]-$} & 939 & - & withanolide derivative & $922(55) 886(63) 856(62) 649(100)$ \\
\hline 18 & 12.4 & 721 & {$[\mathrm{M}+\mathrm{H}]+$} & 719 & {$[\mathrm{M}-\mathrm{H}]-$} & 720 & 452 & withanolide derivative & 703 (44) 592 (65) 574 (100) 556 (30) 453 (8) \\
\hline 19 & 12.6 & 778 & {$[\mathrm{M}+\mathrm{H}]+$} & 776 & {$[\mathrm{M}-\mathrm{H}]-$} & 777 & 452 & withanolide derivative & 760 (8) 703 (28) 649 (100) 631 (81) 453 (11) \\
\hline 20 & 12.9 & 897 & {$[\mathrm{M}+\mathrm{H}]+$} & 895 & $\begin{array}{c}{[\mathrm{M}-\mathrm{H}]-} \\
{[\mathrm{M}+}\end{array}$ & 896 & $502 ?$ & withanolide derivative & 879 (100) 689 (38) 503 (8) 486 (11) 468 (7) \\
\hline 21 & 13.0 & 800 & {$\left[\mathrm{M}+\mathrm{NH}_{4}\right]+$} & 827 & $\begin{array}{c}\mathrm{HCOO}]- \\
{[\mathrm{M}+}\end{array}$ & 782 & 458 & withanolide dihexoside & 783 (8) 621 (97) 459 (100) 441 (19) 423 (10) \\
\hline 22 & 14.0 & 800 & {$\left[\mathrm{M}+\mathrm{NH}_{4}\right]+$} & 827 & $\mathrm{HCOO}]-$ & 782 & 458 & withanolide dihexoside & 783 (71) 621 (25) 459 (100) 441 (76) 423 (41) 405 (25) \\
\hline \multicolumn{10}{|c|}{21} \\
\hline
\end{tabular}




\begin{tabular}{|c|c|c|c|c|c|c|c|c|}
\hline 23 & 14.1 & 934 & {$[\mathrm{M}+\mathrm{H}]+$} & 932 & {$[\mathrm{M}-\mathrm{H}]-$} & 933 & - & - \\
\hline 24 & 14.2 & 715 & {$[\mathrm{M}+\mathrm{H}]+$} & - & $\overline{-}$ & 714 & 470 & withanolide derivative \\
\hline 25 & 14.4 & 816 & {$\left[\mathrm{M}+\mathrm{NH}_{4}\right]+$} & 843 & $\mathrm{HCOO}]-$ & 798 & 456 & withanolide dihexoside \\
\hline 26 & 14.5 & 489 & {$[\mathrm{M}+\mathrm{H}]+$} & - & $\overline{\mathrm{M}}+$ & 488 & - & withanolide \\
\hline 27 & 14.7 & 800 & {$\left[\mathrm{M}+\mathrm{NH}_{4}\right]+$} & 827 & $\mathrm{HCOO}]-$ & 782 & 458 & withanolide dihexoside \\
\hline 28 & 15.0 & 762 & {$[\mathrm{M}+\mathrm{H}]+$} & 760 & {$[\mathrm{M}-\mathrm{H}]-$} & 761 & 454 & withanolide derivative \\
\hline 29 & 15.1 & 650 & {$\left[\mathrm{M}+\mathrm{NH}_{4}\right]+$} & - & - & 632 & 470 & withanolide monohexoside \\
\hline 30 & 15.2 & 638 & {$\left[\mathrm{M}+\mathrm{NH}_{4}\right]+$} & - & - & 620 & 458 & withanolide monohexoside \\
\hline 31 & 15.4 & 762 & {$[\mathrm{M}+\mathrm{H}]+$} & 760 & {$[\mathrm{M}-\mathrm{H}]-$} & 761 & 454 & withanolide derivative \\
\hline$* 32$ & 15.5 & 976 & {$[\mathrm{M}+\mathrm{H}]+$} & 974 & $\begin{array}{c}{[\mathrm{M}-\mathrm{H}]-} \\
{[\mathrm{M}+}\end{array}$ & 975 & - & - \\
\hline 33 & 15.8 & 654 & {$\left[\mathrm{M}+\mathrm{NH}_{4}\right]+$} & 681 & HCOO]- & 636 & 458 & withanolide monohexuronide \\
\hline 34 & 16.3 & 705 & {$[\mathrm{M}+\mathrm{H}]+$} & 703 & {$[\mathrm{M}-\mathrm{H}]-$} & 704 & 454 & withanolide derivative \\
\hline 35 & 17.0 & 784 & {$\left[\mathrm{M}+\mathrm{NH}_{4}\right]+$} & 811 & $\begin{array}{c}{[\mathrm{M}+} \\
\mathrm{HCOO}]-\end{array}$ & 766 & 442 & $\begin{array}{l}\text { withanolide dihexoside } \\
\text { (indicative of withanoside V) }\end{array}$ \\
\hline$* * 36$ & 17.4 & 471 & {$[\mathrm{M}+\mathrm{H}]+$} & - & - & 470 & - & withaferin A \\
\hline 37 & 18.3 & 730 & {$[\mathrm{M}+\mathrm{H}]+$} & 728 & {$[\mathrm{M}-\mathrm{H}]-$} & 729 & - & - \\
\hline 38 & 18.6 & 471 & {$[\mathrm{M}+\mathrm{H}]+$} & - & - & 470 & - & withanolide \\
\hline 39 & 19.4 & 569 & {$[\mathrm{M}+\mathrm{H}]+$} & 567 & {$[\mathrm{M}-\mathrm{H}]-$} & 568 & 488 & withanolide sulphate \\
\hline 40 & 19.8 & 488 & {$\left[\mathrm{M}+\mathrm{NH}_{4}\right]+$} & - & - & 470 & - & withanolide \\
\hline 41 & 20.3 & 569 & {$[\mathrm{M}+\mathrm{H}]+$} & 567 & {$[\mathrm{M}-\mathrm{H}]-$} & 568 & 488 & withanolide sulphate \\
\hline 42 & 22.8 & 586 & {$\left[\mathrm{M}+\mathrm{NH}_{4}\right]+$} & 567 & {$[\mathrm{M}-\mathrm{H}]-$} & 568 & 488 & withanolide sulphate \\
\hline 43 & 23.4 & 280 & {$[\mathrm{M}+\mathrm{H}]+$} & - & - & 279 & - & - \\
\hline 44 & 24.1 & 569 & {$[\mathrm{M}+\mathrm{H}]+$} & 567 & {$[\mathrm{M}-\mathrm{H}]-$} & 568 & 488 & withanolide sulphate \\
\hline
\end{tabular}

916 (20) 726 (53) 579 (40) 562 (100) 544 (30) 518 (22) 356 (11)

679 (33) 622 (53) 471 (100) 299 (33) 281 (15)

799 (6) 619 (30) 457 (100) 439 (64) 421 (35) 403 (6) 317 (100) 299 (37) 281 (16)

783 (6) 603 (44) 459 (8) 441 (100) 423 (8) 405 (9) 744 (7) 633 (100) 616 (61) 455 (24)

$471(100)$

621 (7) 603 (14) 459 (100) 441 (72) 423 (27) 405 (12) 744 (7) 633 (76) 615 (100) 455 (34)

772 (23) 604 (100) 417 (25)

457 (100) 439 (53) 421 (19) 403 (3)

687 (20) 455 (26) 437 (94) 419 (100) 401 (67)

767 (20) 605 (19) 443 (100) (425 (24) 407 (7)

435 (10) 299 (74) 281 (100) 175 (6)

712 (20) 601 (41) 583 (100) 423 (77) 405 (48)

453 (15) 435 (100) 417 (94) 399 (63) 371 (17) 263 (49) 211 (22) 197 (13)

533 (17) 515 (28) 497 (32) 453 (73) 435 (91) 417 (78) 397 (49) 361 (100) 283 (20)

471 (65) 453 (100) 435 (32) 417 (71) 399 (54) 289 (23) 263 (36)

489 (5) 453 (5) 397 (100) 317 (11) 299 (6) 281 (6)

569 (44) 551 (100) 533 (15) 515 (15) 453 (17) 417 (40) 399 (15) 389 (18) 361 (11)

$263(100)$

ionisation in positive mode too low

*The dimeric thiowithanolide, ashwagandhanolide, with the same $\mathrm{M}_{\mathrm{r}}$ as $\mathbf{3 2}$ has been reported by Subbaraju et al. (2006).

**Peak assigned as withaferin A by comparison with a reference standard for withaferin $\mathrm{A}$ 


1
2
3
4
5
6
7
8
9
10
11
12
13
14
15
16
17
18
19
20
21
22
23
24
25
26
27
28
29
30
31
32
33
34
35
36
37
38
39
40
41
42
43
44
45
46
47
48
49
50
51
52
53
54
55
56
57
58
60

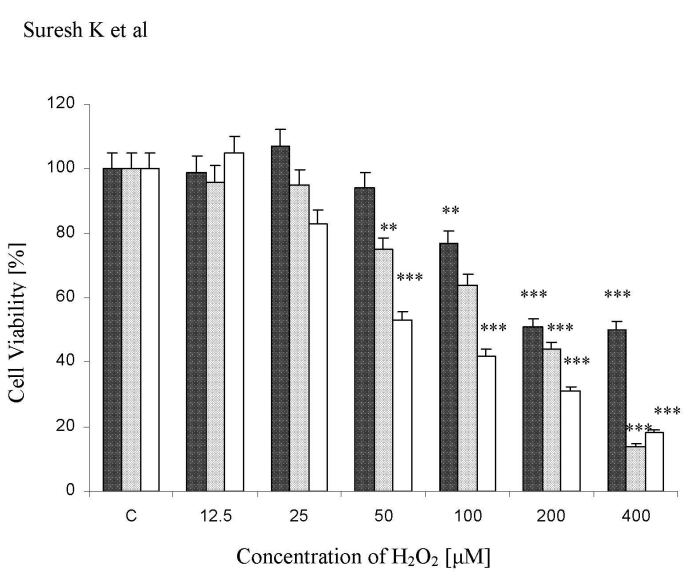

Fig. 1

$209 \times 297 \mathrm{~mm}(300 \times 300$ DPI $)$ 


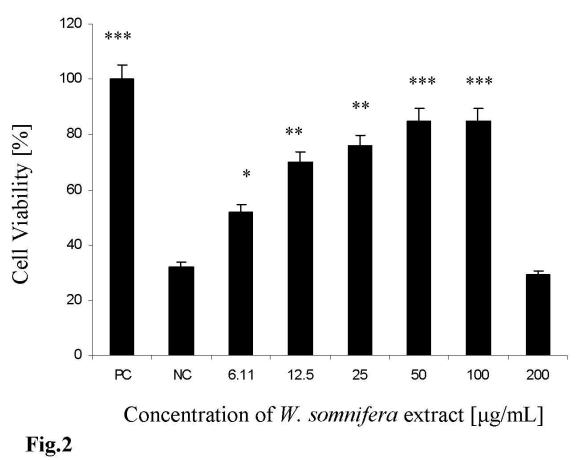

209x297mm (300 x 300 DPI)

http://mc.manuscriptcentral.com/ptr 


1
2
3
4
5
6
7
8
9
10
11
12
13
14
15
16
17
18
19
20
21
22
23
24
25
26
27
28
29
30
31
32
33
34
35
36
37
38
39
40
41
42
43
44
45
46
47
48
49
50
51
52
53
54
55
56
57
58
60

Suresh K et al

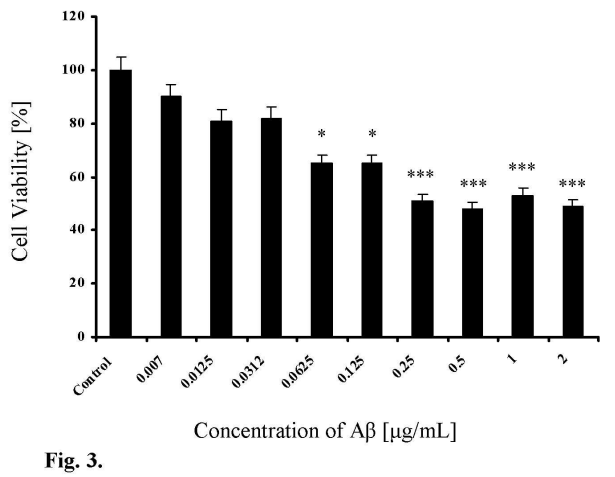

$209 \times 297 \mathrm{~mm}(300 \times 300 \mathrm{DPI})$

http://mc.manuscriptcentral.com/ptr 


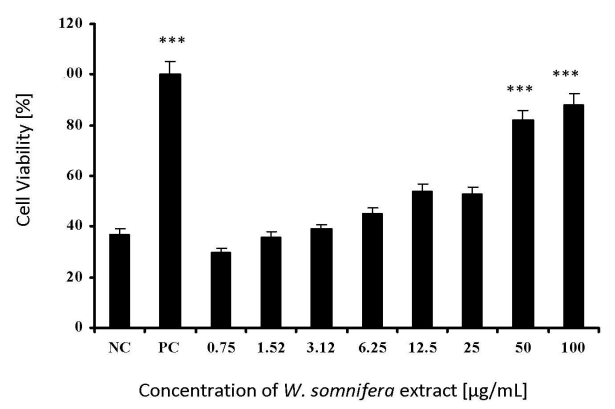

Fig. 4 


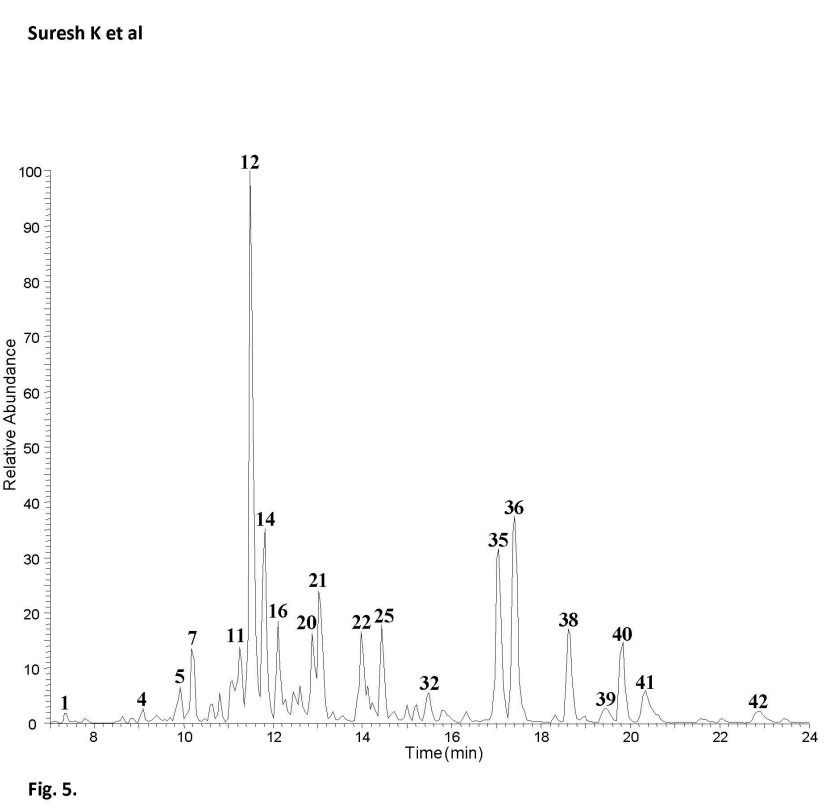

$209 \times 297 \mathrm{~mm}(300 \times 300 \mathrm{DPI})$ 